\title{
Subepithelial immunopathology of the large airways in smokers with and without chronic obstructive pulmonary disease
}

\author{
B.E.A. Lams, A.R. Sousa, P.J. Rees, T.H. Lee
}

\begin{abstract}
Subepithelial immunopathology of the large airways in smokers with and without chronic obstructive pulmonary disease. B.E.A. Lams, A.R. Sousa, P.J. Rees, T.H. Lee. (C)ERS Journals Ltd 2000

ABSTRACT: Previous work has shown an increase in CD8+ T-cells, neutrophils and eosinophils in small airway subepithelium in smokers. The authors have now investigated whether similar changes occur in the large airways.

Immunohistochemistry on frozen sections of bronchial biopsies were obtained at bronchoscopy in 11 nonsmokers, eight asymptomatic smokers and 11 smokers with chronic bronchitis and chronic obstructive pulmonary disease (COPD).

There was an increase in the number of CD8+ cells infiltrating the bronchial subepithelium in the COPD group compared to the asymptomatic smokers (305 (109400) versus $92(41-550)$ cells $\left.\cdot \mathrm{mm}^{-2}, \mathrm{p}=0.030\right)$. There was a negative correlation between the number of CD8+ cells and the forced expiratory volume in one second (FEV1) \% predicted $(\mathrm{p}=\mathbf{0 . 0 0 5}, \mathrm{r}=-\mathbf{0 . 6 2})$, and a positive correlation between the number of CD8+ cells and the number of pack years smoked $(p=0.017, r=0.42)$. There was a negative correlation between the activated/total eosinophils ratio and the FEV1 \% pred $(p=0.017, r=-0.51)$. There was a negative correlation between pack years smoked and the number of neutrophils $(p=0.022, r=-0.36)$.

Smokers who develop chronic obstructive pulmonary disease have increased numbers of CD8+ T-cells in large airways when compared to asymptomatic smokers. Airway obstruction was associated with an increase in the proportion of eosinophils that were activated.
\end{abstract}

Eur Respir J 2000; 15: 512-516.

Smoking is the major cause of chronic obstructive pulmonary disease (COPD), a disease which is characterized by fixed airflow obstruction [1]. However only $20 \%$ of smokers eventually develop clinically significant COPD, suggesting that host factors might be important in the development of airflow obstruction [2]. There is increasing evidence that inflammation plays an important role in the pathogenesis of COPD although there is conflicting information as to the cellular nature of the inflammatory infiltrate at different sites in the lung.

Previous studies have demonstrated an increase in the number of T-cells infiltrating the large airway subepithelium and a shift towards a CD8 phenotype [3-8] in addition to increases in the number of macrophages $[4,5,8]$. An increase in the number of infiltrating eosinophils has been observed in the large airway subepithelium although they do not appear to be degranulated as in asthma [9]. Although studies examining bronchoalveolar lavage have demonstrated increases in the number of neutrophils in subjects with COPD [10-14] this has not been supported by the majority of studies of the large airway subepithelium $[4,5,8,11]$.

It has previously been demonstrated that there is a shift in the T-cell phenotype towards CD8+ and an increase in neutrophils and eosinophils infiltrating the small airway subepithelium in smokers, when compared to nonsmokers [15]. In order to investigate whether a similar change in the inflammatory cell population occurs in the large airway subepithelium, the authors have applied immunohistochemistry to bronchial biopsies obtained at bronchoscopy in a group of nonsmokers, asymptomatic smokers, and smokers with COPD.

\section{Methods}

\section{Subjects}

In order to study the cellular infiltration in the bronchial mucosa the authors obtained bronchial biopsies at bronchoscopy as previously described [16] in a group of 11 nonsmokers (NS) (age 52.5 \pm 2.8 yrs (mean $\pm \mathrm{SD}$ ), forced expiratory volume in one second (FEV1) $101.1 \pm 4.5 \%$ pred (mean \pm SEM)), eight asymptomatic smokers (S) (age $50.5 \pm 2.6$ yrs (mean \pm SEM), FEV $1101 \pm 4.5 \%$ pred (mean \pm SEM)), and 11 smokers with COPD and chronic bronchitis, defined as an FEV $1<80 \%$ pred in addition to the presence of a cough productive of sputum on most days for at least 3 months in a year for at least 2 yrs (COPD) [16] (age $59.9 \pm 3.0$ yrs (mean \pm SEM), FEV1 $56.8 \pm 4.7 \%$ pred (mean \pm SEM) (table 1). Nonsmokers and asymptomatic smokers were recruited from healthy volunteers. Subjects with COPD were recruited from outpatient clinics. They were excluded from the study if they had had an exacerbation 
Table 1. - Characteristics of subjects

\begin{tabular}{lrrrrc}
\hline & $\mathrm{n}$ & Males & Age & FEV1 & Pack years \\
\hline Nonsmokers & 11 & 4 & $53+3$ & $101 \pm 5$ & 0 \\
Asymptomatic smokers & 8 & 4 & $51 \pm 3$ & $101 \pm 5$ & $40 \pm 6$ \\
Smokers with COPD & 11 & 8 & $60 \pm 3$ & $57 \pm 5$ & $53 \pm 11$ \\
\hline
\end{tabular}

Data are expressed as absolute numbers and mean \pm SEM. FEV1: forced expiratory volume in one second; COPD: chronic obstructive pulmonary disease.

in the previous 2 months, were taking inhaled steroids, or had a history of asthma, eczema or allergic rhinitis. All subjects underwent spirometry (Medisoft PulmoLink Partn'Air 5500; Medisoft, Dinant, Belgium) and were excluded if reversibility to $1 \mathrm{mg}$ inhaled terbutaline assessed after $15 \mathrm{~min}>15 \%$ of initial value of FEV1. Subjects also had skin-prick tests to a battery of common aeroallergens (ALK, Horsholm, Denmark) and were excluded if any reaction was $>2 \mathrm{~mm}$.

\section{Immunohistochemistry}

Bronchial biopsies were snap frozen in OCT embedding medium (Miles, Elkhart, IN, USA) in isopentane (BDH, Poole, Dorset, UK) cooled over liquid nitrogen. Samples were stored at $-70^{\circ} \mathrm{C}$. Consecutive $5 \mu \mathrm{m}$ frozen sections were then cut and used for immunohistochemistry as previously described [17] using the avidin biotin complex. Mouse monoclonal immunoglobulin (Ig)G1 primary antiodies were used for cell identification as follows: anti-CD3 (MO835; DAKO, High Wycombe, UK) a panT-lymphocyte marker used at 1:50 dilution; anti-CD4 (MO716; DAKO) used at 1:50 dilution; anti-CD8 (MO707; DAKO) used at 1:50 dilution; EBM11 (MO718; DAKO) a pan-macrophage marker recognizing CD68 used at 1:100 dilution; NP57 (MO752; DAKO) an antihuman neutrophil elastase (NE) antibody to identify neutrophils used at 1:600 dilution; BMK13 (CBL419; Cymbus Bioscience Ltd, Chilworth, UK) a pan-eosinophil marker recognizing major basic protein (MBP) used at 1:40 dilution; EG2 (10/9196/01; Pharmacia, Uppsala, Sweden) a marker for activated eosinophils recognising the cleaved activated form of the eosinophilic cationic protein (ECP) used at 1:100; and ACT-1(MO731; DAKO) a marker for activated T-cells recognizing the interleukin (IL)-2 receptor (CD25) used at 1:50 dilution. Rabbit antimouse biotinylated antibody (EO354; DA-KO) was used as a secondary antibody at a dilution of 1:400. Endogenous biotin and peroxidase activity was abolished as previously described [17]. The immunoperoxidase colour reaction was developed by incubation with diaminobenzidine. A positive control using nasal polyp tissue and a negative control without primary anti-body were included in each staining run.

\section{Cell counts}

The number of cells positive for the appropriate cell marker was counted by a blinded investigator in the subepithelium of each biopsy section, excluding areas of smooth muscle and mucous secreting glands when these were identified. One section from one biopsy from each subject was analysed for each antibody. The relevant area was outlined on a captured image and the contained area measured using image analysis software (Colour FreeLance software, Sight Systems, Hove, Sussex, UK). All cell counts were expressed as cells $\cdot \mathrm{mm}^{-2}$. Some sections were inevitably lost in the staining procedure during the repeated incubations and washing required by the technique of immunohistochemistry and this accounts for the occasional missed cases in some cell counts.

\section{Statistical analysis and ethics}

Statistical analyses of the data were performed using the Kruskal-Wallis test with a Dunns post test. Correlations were assessed using a Spearman test. Results are expressed as median (range). A p-value of $<0.05$ was considered statistically significant. The study was approved by the Guy's and St Thomas' Hospitals Ethics committees. All subjects gave written informed consent.

\section{Results}

T-cells

No significant difference was detected in the number of CD3+ cells (total T-cells) infiltrating the large airway subepithelium between the NS (451 (138-996) cells $\cdot \mathrm{mm}^{-2}$, $\mathrm{n}=10)$, the $\mathrm{S}\left(330(182-1062)\right.$ cells $\left.\cdot \mathrm{mm}^{-2}, \mathrm{n}=8\right)$ and the COPD (560 (183-1520) cells $\left.\cdot \mathrm{mm}^{-2}, \mathrm{n}=9\right)$. However, there was a negative correlation between the number of CD3+ cells infiltrating the large airway subepithelium and the FEV1 \% pred when all smokers were analysed $(p=0.029$, $\mathrm{r}=-0.47, \mathrm{n}=17)$. There was no difference in the number of CD25+ cells (activated T-cells) between the NS (3.1 (0$21.4)$ cells $\left.\cdot \mathrm{mm}^{-2}, \mathrm{n}=11\right)$, the $\mathrm{S}\left(3.0(0-27.6)\right.$ cells $\cdot \mathrm{mm}^{-2}$, $\mathrm{n}=8)$ and the COPD $\left(3.38(0-42.8)\right.$ cells $\left.\cdot \mathrm{mm}^{-2}, \mathrm{n}=10\right)$.

There was an increase in the number of CD8+ cells infiltrating the large airway subepithelium when the COPD (305 (109-400) cells $\left.\cdot \mathrm{mm}^{-2}, \mathrm{n}=8\right)$ were compared to the $\mathrm{S}$ (92 (41-550) cells $\left.\cdot \mathrm{mm}^{-2}, \mathrm{n}=8, \mathrm{p}=0.030\right)$ (fig. 1a). In addition there was a negative correlation between the number of CD8+ cells infiltrating the large airway subepithelium and the FEV1 \% pred when all smokers were analysed $(\mathrm{p}=0.005, \mathrm{r}=-0.62, \mathrm{n}=16)$ (fig. $1 \mathrm{~b})$ and a positive correlation between the number of CD8+ cells infiltrating the large airway subepithelium and the number of pack years smoked when all smokers were analysed $(\mathrm{p}=0.006, \mathrm{r}=$ $0.61, n=16$ ) (fig. 1c). There was no significant difference in the number of CD8+ cells infiltrating the large airway subepithelium between the NS $\left(145(20-260)\right.$ cells. $\mathrm{mm}^{-2}$, $\mathrm{n}=10)$ and either the COPD (305 (109-400) cells $\cdot \mathrm{mm}^{-2}$, $\mathrm{n}=8)$ or the $\mathrm{S}\left(92(41-550)\right.$ cells $\left.\cdot \mathrm{mm}^{-2}, \mathrm{n}=8\right)$.

No significant difference was detected between the number of CD4+ cells infiltrating the large airway subepithelium between the NS $\left(321(92-498)\right.$ cells $\cdot \mathrm{mm}^{-2}, \mathrm{n}=$ $11)$, the $\mathrm{S}\left(156(70-372)\right.$ cells $\left.\cdot \mathrm{mm}^{-2}, \mathrm{n}=7\right)$ and the COPD (244 (0-591) cells $\left.\cdot \mathrm{mm}^{-2}, \mathrm{n}=11\right)$.

\section{Eosinophils}

No significant difference was detected between the number of MBP positive cells (total eosinophils) between the NS (129 (27-282) cells. $\left.\mathrm{mm}^{-2}, \mathrm{n}=11\right)$, the S (99 (34300) cells $\left.\cdot \mathrm{mm}^{-2}, \mathrm{n}=8\right)$ and the COPD (63 (12.5-166) cells $\left.\cdot \mathrm{mm}^{-2}, \mathrm{n}=10\right)$. There was a weak positive correlation 


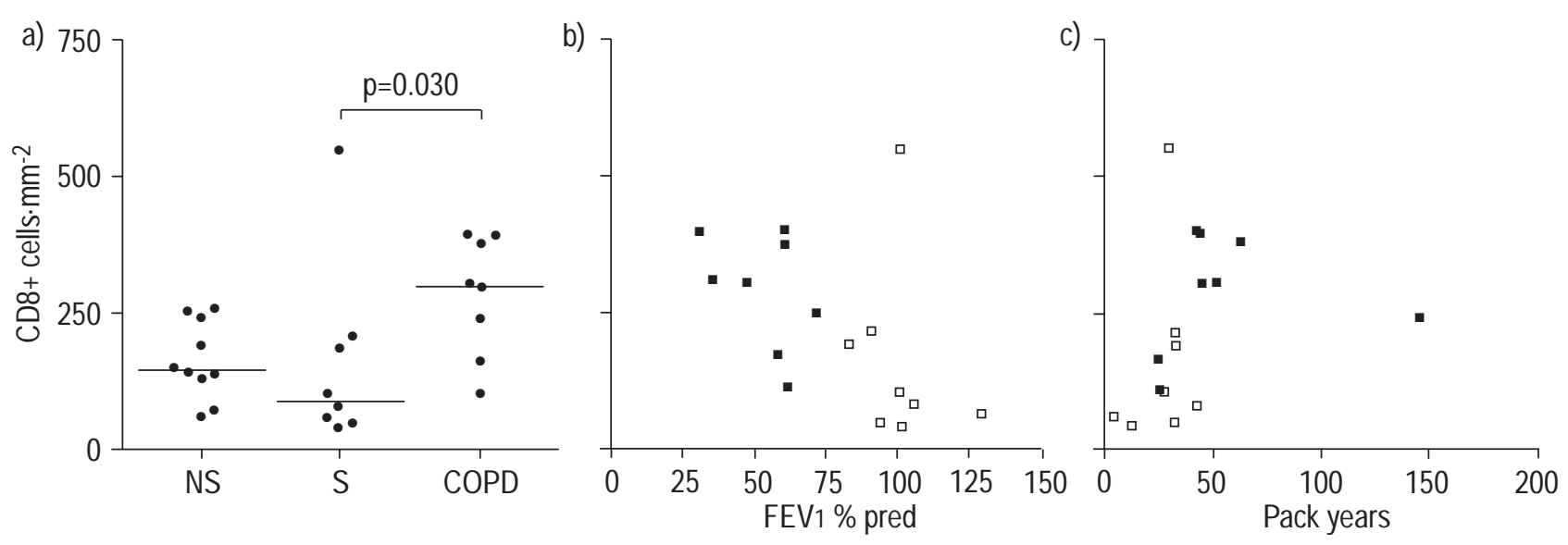

Fig. 1. - a) Number of CD8+ cells infiltrating large airway subepithelium obtained from 10 nonsmokers (NS), eight asymptomatic smokers (S) and eight smokers with chronic obstructive pulmonary disease (COPD). b) Relationship between number of CD8+ cells infiltrating large airway subepithelium and forced expiratory volume in one second (FEV1) \% predicted in all smoking subjects $(\mathrm{n}=16)(\square$ : asymptomatic smokers open squares; $\square$ : smokers with COPD). $\mathrm{p}=0.005, \mathrm{r}=-0.62$. c) Relationship between number of CD8+ cells infiltrating large airway subepithelium and pack years smoked in all smoking subjects ( $\mathrm{n}=16)$ ( $\square$ : asymptomatic smokers; $\square$ : smokers with COPD). $\mathrm{p}=0.006, \mathrm{r}=0.61$. Horizontal lines represent mean values.

between the number of MBP positive cells infiltrating the large airway subepithelium and the FEV1 \% pred when all smokers were analysed ( $\mathrm{p}=0.043, \mathrm{r}=0.42, \mathrm{n}=18$ ) (fig. $2 \mathrm{a})$. No significant difference was detected between the number of EG2 positive cells (activated eosinophils) between the NS $\left(17(0-103)\right.$ cells $\left.\cdot \mathrm{mm}^{-2}, \mathrm{n}=9\right)$, the $\mathrm{S}(8.9(0-27)$ cells $\left.\cdot \mathrm{mm}^{-2}, \mathrm{n}=8\right)$ and the COPD $\left(19(0-91)\right.$ cells $\cdot \mathrm{mm}^{-2}$, $\mathrm{n}=10$ ). There was a negative correlation between the EG2 positive/MBP positive ratio of cells infiltrating the large airway subepithelium and the FEV1 \% pred when all smokers were analysed ( $p=0.017, r=-0.51, n=17$; fig. $2 b)$.

\section{Neutrophils}

No significant difference was detected between the number of NE positive cells (neutrophils) between the NS (247 (89-684) cells $\left.\cdot \mathrm{mm}^{-2}, \mathrm{n}=11\right)$, the S (190 (57-267) cells $\left.\cdot \mathrm{mm}^{-2}, \mathrm{n}=8\right)$ and the COPD (165 (29-578) cells $\cdot \mathrm{mm}^{-2}$, $\mathrm{n}=11$ ). There was a negative correlation between the number of NE positive cells infiltrating the large airway subepithelium and the number of pack years smoked when all smokers were analysed $(\mathrm{p}<0.001, \mathrm{r}=-0.69, \mathrm{n}=19)$.

\section{Macrophages}

No significant difference was detected between the number of EBM11 positive cells (macrophages) between the NS (321 (192-575) cells $\left.\mathrm{mm}^{-2}, \mathrm{n}=10\right)$, the S $(249(162-$ 1009) cells $\left.\cdot \mathrm{mm}^{-2}, \mathrm{n}=8\right)$ and the smokers with COPD (420 $(163-566)$ cells $\left.\cdot \mathrm{mm}^{-2}, \mathrm{n}=10\right)$.

\section{Discussion}

This is the first study to demonstrate an increase in the number of CD8+ cells infiltrating the large airway subepithelium in a group of smokers with COPD when compared to a group of smokers without COPD. In addition the data demonstrate that in smokers without COPD there is no increase in the number of CD8+ cells when compared with nonsmokers. These two observations suggest that CD8+ cells may play a central role in the pathogenesis of COPD. These results are consistent with those of O'SHAUGHNESSY et al. [8] who demonstrated an increase in CD8+ infiltration into the large airways in a group of subjects with

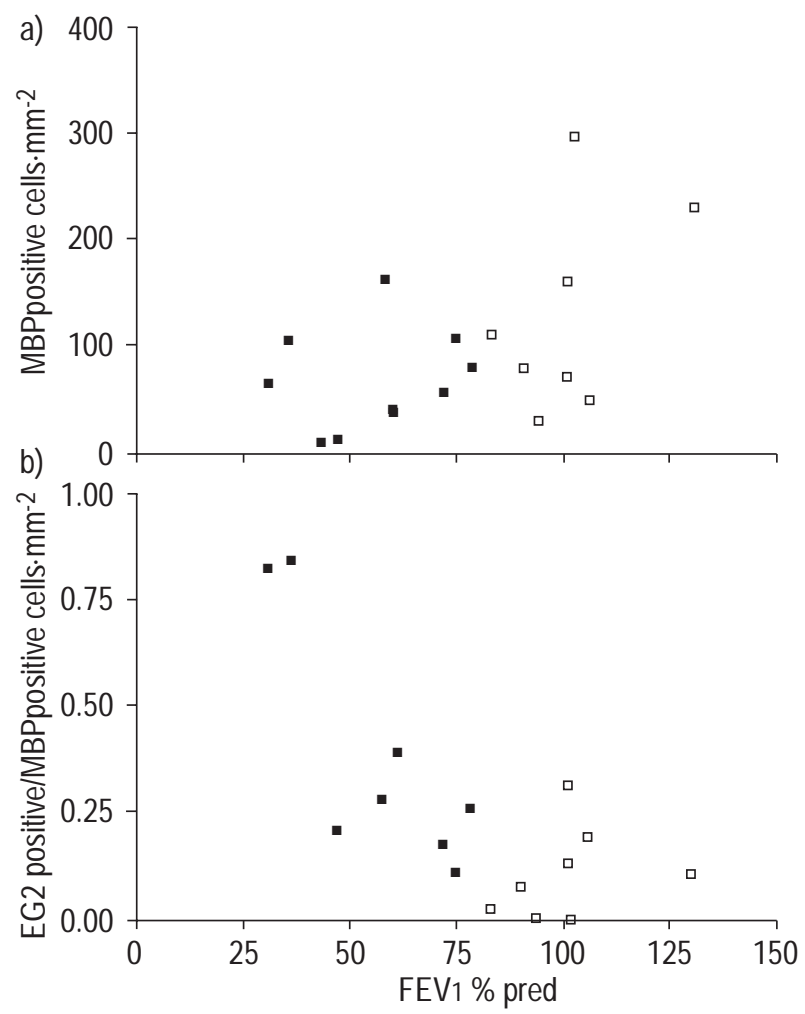

Fig. 2. - a) Relationship between number of major basic protein (MBP) positive cells infiltrating large airway subepithelium and forced expiratory volume in one second (FEV1) \% predicted in all smoking subjects $(\mathrm{n}=18)(\square$ : asymptomatic smokers; $\square$ : smokers with chronic obstructive pulmonary disease (COPD)). $\mathrm{p}=0.043$, $\mathrm{r}=0.42$. b) Relationship between ratio of EG2 positive cells (activated eosinophils) to MBP positive cells (total eosinophils) infiltrating large airway subepithelium and $\mathrm{FEV}_{1} \%$ pred in all smoking subjects $(\mathrm{n}=17)(\square$ : asymptomatic smokers; $\mathbf{\square}$ : smokers with COPD). $\mathrm{p}=0.017, \mathrm{r}=-0.51$ 
COPD when compared to a group of nonsmokers and a positive correlation with increasing obstruction. A shift towards CD8+ T-cells in the small airways has previously been demonstrated in smokers [15] and SAETTA et al. [18] have previously demonstrated CD8+ infiltration into the small airways in COPD, suggesting that these cells play a role at different levels of airway within the lung.

In addition to their accepted role as cytotoxic cells, CD8+ cells are known to be capable of inducing lung damage when present in excess [19]. There is increasing evidence for their role in the regulation of the inflammatory response through the release of cytokines [20,21]. A recent study has demonstrated genetic control of the ratio between $\mathrm{CD} 8+$ and $\mathrm{CD} 4+$ cells with a small $(5 \%)$ percentage of the population having a CD4/CD8 ratio of $<1$ [22]. The current data would be consistent with the hypothesis, suggested by $\mathrm{O}^{\prime}$ SHAUGHNESSY et al. [8], that those with a genetically determined increase in the CD8+ population may be more susceptible to a further increase in CD8+ cells induced by smoking. This hypothesis might also explain the overlap between the number of CD8+ve cells between the nonsmokers and the asymptomatic smokers. Subpopulations of subjects with high and low CD8+ cells may be present in the nonsmoking group whereas a subpopulation with low CD8+ cells is selected in the smokers who are resistant to the development of COPD and a subpopulation with high CD8+ cells is selected in the group of smokers who do develop COPD.

The finding of a positive correlation between the EG2 positive cells/MBP positive ratio of cells infiltrating the large airway subepithelium (which can be taken as an approximation of the ratio of activated eosinophils to total eosinophils) and increasing obstruction, suggests that increasing airways obstruction is associated with an increase in the fraction of those eosinophils that are activated.

The demonstration of an inverse relationship between the number of infiltrating neutrophils and pack years is consistent with another previous study which has noted a similar reduction in the number of neutrophils infiltrating the alveolar septum associated with cigarette smoking [23]. However, the data are in contrast to the authors' previous findings [15] and those of BosKen et al. [24] in which amount smoked correlated positively with the number of infiltrating neutrophils in the small airways. This may reflect differences between the large and small airways in the inflammatory response induced by cigarette smoke.

The absence of any correlation between the number of neutrophils infiltrating the large airway subepithelium and increasing obstruction is consistent with previous studies which have reported no increase in neutrophils in the large $[4,5,8,11]$ or the small airways $[15,24]$ in subjects with COPD. The discordance of these results with those showing an increase in numbers of neutrophils and markers of neutrophil activation in bronchoalveolar lavage $[10,11$, $13,14,25]$, induced sputum [26-28] and airway epithelium [29] remains to be explained.

In conclusion, this study demonstrates an increase in the number of CD8+ T-cells infiltrating the large airway subepithelium in a group of smokers with chronic obstructive pulmonary disease when compared with an asymptomatic group of smokers, supporting the central role of CD8+ cells in the pathogenesis of chronic obstructive pulmonary disease. Further research is needed to investigate the me- chanisms by which CD8+ve cells may induce the fixed airflow obstruction characteristic of chronic obstructive pulmonary disease.

\section{References}

1. Doll R, Peto R. Mortality in relation to smoking: 20 years' observation on British male doctors. BMJ 1976; 2: 15251535.

2. Fletcher C, Peto R. The natural history of chronic airflow obstruction. BMJ 1977; 1: 1645-1648.

3. Fournier M, Lebargy F, Le Roy LF, Lenormand E, Pariente R. Intraepithelial T-lymphocyte subsets in the airways of normal subjects and of patients with chronic bronchitis. Am Rev Respir Dis 1989; 140: 737-742.

4. Di Stefano A, Turato G, Maestrelli P, et al. Airflow limitation in chronic bronchitis is associated with T-lymphocyte and macrophage infiltration of the bronchial mucosa. Am J Respir Crit Care Med 1996; 153: 629-632.

5. Saetta M, Di Stefano A, Maestrelli P, et al. Activated Tlymphocytes and macrophages in bronchial mucosa of subjects with chronic bronchitis. Am Rev Respir Dis 1993; 147: 301-306.

6. Saetta M, Di Stefano A, Maestrelli P, et al. Airway eosinophilia in chronic bronchitis during exacerbations. Am J Respir Crit Care Med 1994; 150: 1646-1652.

7. Mueller R, Chanez P, Campbell AM, Bousquet J, Heusser C, Bullock GR. Different cytokine patterns in bronchial biopsies in asthma and chronic bronchitis. Respir Med 1996; 90: 79-85.

8. O'Shaughnessy TC, Ansari TW, Barnes NC, Jeffery PK. Inflammation in bronchial biopsies of subjects with chronic bronchitis: inverse relationship of CD8+ T lymphocytes with FEV1. Am J Respir Crit Care Med 1997; 155: 852-857.

9. Bousquet J, Chanez P, Campbell AM, et al. Inflammatory processes in asthma. Int Arch Allergy Appl Immunol 1991; 94: 227-232.

10. Martin TR, Raghu G, Maunder RJ, Springmeyer SC. The effects of chronic bronchitis and chronic air-flow obstruction on lung cell populations recovered by bronchoalveolar lavage. Am Rev Respir Dis 1985; 132: 254-260.

11. Lacoste JY, Bousquet J, Chanez P, et al. Eosinophilic and neutrophilic inflammation in asthma, chronic bronchitis, and chronic obstructive pulmonary disease. J Allergy Clin Immunol 1993; 92: 537-548.

12. Thompson AB, Daughton D, Robbins RA, Ghafouri MA, Oehlerking M, Rennard SI. Intraluminal airway inflammation in chronic bronchitis. Characterization and correlation with clinical parameters. Am Rev Respir Dis 1989; 140: $1527-1537$.

13. Costabel U, Maier K, Teschler H, Wang YM. Local immune components in chronic obstructive pulmonary disease. Respiration 1992; 59: (Suppl. 1), 17-19.

14. Lusuardi M, Capelli A, Cerutti CG, Spada EL, Donner CF. Airways inflammation in subjects with chronic bronchitis who have never smoked. Thorax 1994; 49: 12111216.

15. Lams BEA, Sousa AR, Rees PJ, Lee TH. Immunopathology of the small airway submucosa in smokers with and without COPD. Am Rev Respir Crit Care Med 1998; 158: $1518-1523$.

16. BTS Guidelines for the Management of COPD. Thorax 1997; 52: Suppl. 5, pp. 1-28.

17. Nasser SM, Pfister R, Christie PE, et al. Inflammatory 
cell populations in bronchial biopsies from aspirin-sensitive asthmatic subjects. Am J Respir Crit Care Med 1996; 153: 90-96.

18. Saetta M, Di Stefano A, Turato G, et al. CD8+ T-lymphocytes in peripheral airways of smokers with chronic obstructive pulmonary disease. Am J Respir Crit Care Med 1998; 157: 822-826.

19. Cannon MJ, Oppenshaw PJM, Askonas A. Cytotoxic Tcells clear virus but augment lung pathology in mice infected with respiratory syncytial virus. $J$ Exp Med 1988; 168: 1163-1168.

20. Coyle AJ, Erard F, Bertrand C, Walti S, Pircher H, Le Gros G. Virus-specific CD8+ cells can switch to interleukin 5 production and induce airway eosinophilia. $J \operatorname{Exp}$ Med 1995; 181: 1229-1233.

21. Gesser B, Deleuran B, Lund $\mathrm{M}$, et al. Interleukin-8 induces its own production in CD4+ $\mathrm{T}$ lymphocytes: a process regulated by interleukin 10. Biochem Biophys Res Comm 1997; 210: 660-669.

22. Amadori A, Zamarchi R, De Silvestro G, et al. Genetic control of the CD4/CD8 T-cell ratio in humans. Nature Med 1995; 1: 1279-1283.

23. Finkelstein R, Fraser RS, Ghezzo H, Cosio MG. Alveolar inflammation and its relation to emphysema in smokers. Am J Respir Crit Care Med 1995; 152: 1666-1672.
24. Bosken CH, Hards J, Gatter K, Hogg JC. Characterization of the inflammatory reaction in the peripheral airways of cigarette smokers using immunocytochemistry. Am Rev Respir Dis 1992; 145: 911-917.

25. Thompson AB, Daughton D, Robbins RA, Ghafouri MA, Oehlerking M, Rennard SI. Intraluminal airway inflammation in chronic bronchitis. Characterization and correlation with clinical parameters. Am Rev Respir Dis 1989; 140: $1527-1537$.

26. Stanescu D, Sanna A, Veriter C, et al. Airways obstruction, chronic expectoration, and rapid decline of FEV1 in smokers are associated with increased levels of sputum neutrophils. Thorax 1996; 51: 267-271.

27. Keatings VM, Collins PD, Scott DM, Barnes PJ. Differences in interleukin- 8 and tumor necrosis factor-alpha in induced sputum from patients with chronic obstructive pulmonary disease or asthma. Am J Respir Crit Care Med 1996; 153: 530-534.

28. Keatings VM, Evans DJ, O'Connor BJ, Barnes PJ. Cellular profiles in asthmatic airways: a comparison of induced sputum, bronchial washings, and bronchoalveolar lavage fluid. Thorax 1997; 52: 372-374.

29. Pesci A, Majori M, Cuomo A, et al. Neutrophils infiltrating bronchial epithelium in chronic obstructive pulmonary disease. Respir Med 1998; 92: 863-870. 